\title{
BOJAN ERHARTIČ'S CONTRIBUTION TO GEOGRAPHY
}

Aleš Smrekar, Matija Zorn, Blaž Komac

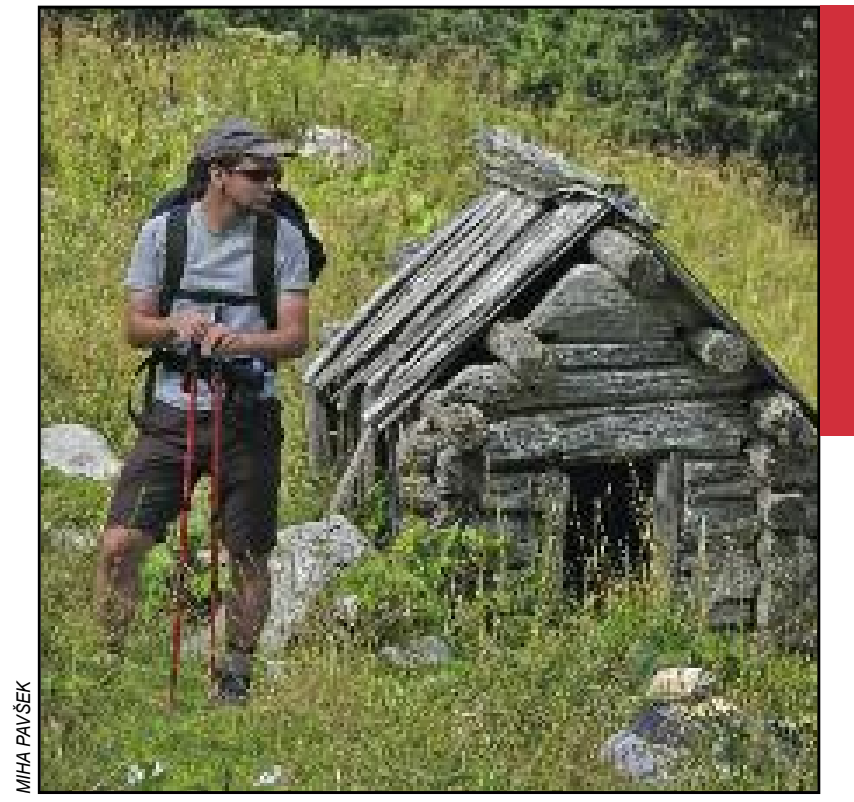

Bojan Erhartič: geomorphologist and conservationist. 


\section{Bojan Erhartič's contribution to geography}

DOI: http://dx.doi.org/10.3986/AGS.3633

UDC: 929ERHARTIČ B.:91

COBISS: 1.02

ABSTRACT: At the beginning of the twenty-first century, Bojan Erhartič had a strong impact on Slovenian geography because he placed it on the map of countries where geographers deal with geomorphological heritage. He began his research path into the world of natural heritage with the study of geography. After receiving his bachelor's degree, he turned his attention to studying geodiversity, and this led him to issues concerning the evaluation of geomorphological heritage, especially in mountainous areas. Erhartič was among the first in Slovenian geography to deal with the aesthetic evaluation of geomorphological heritage. His interest in the »beauty of nature« stemmed from many years of planned work in (geographical) photography. The Anton Melik Geographical Institute of the Research Center of the Slovenian Academy of Sciences and Arts holds approximately 218,000 of his "geographical " photos, which he took during his many travels in more than forty countries on five continents.

KEY WORDS: geography, research, environmental protection, geomorphological heritage, natural values, in memoriam, Bojan Erhartič

The article was submitted for publication on November $11^{\text {th }}, 2015$.

ADDRESSES:

Aleš Smrekar, Ph.D.

Anton Melik Geographical Institute

Research Center of the Slovenian Academy of Sciences and Arts

Gosposka ulica 13, SI - 1000 Ljubljana, Slovenia

E-mail: ales.smrekar@zrc-sazu.si

Matija Zorn, Ph.D.

Anton Melik Geographical Institute

Research Center of the Slovenian Academy of Sciences and Arts

Gosposka ulica 13, SI - 1000 Ljubljana, Slovenia

E-mail:matija.zorn@zrc-sazu.si

Blaž Komac, Ph.D.

Anton Melik Geographical Institute

Research Center of the Slovenian Academy of Sciences and Arts

Gosposka ulica 13, SI - 1000 Ljubljana, Slovenia

E-mail:blaz.komac@zrc-sazu.si 


\section{Introduction}

Bojana Erhartič's research path into the world of natural heritage began with the study of geography, when he started dealing with mountainous areas and their conservation. At the end of his bachelor's program, he wrote the following in his thesis: »With the expansion and modernization of the Triglav Lakes Lodge in the mid-1980s, we came to the realization that the impact of mountain lodges on drinking water in the Alps was becoming a serious problem " (Erhartič 2004, 1). Soon after he graduated, he turned his attention to studying geodiversity, or the diversity of nonliving nature (Erhartič 2007). This led him to questions concerning its scientific value. He especially dedicated himself to evaluating geomorphological heritage and its conservation (Erhartič 2011,2012), and also to the application of these findings in society (Erhartič and Šmid Hribar 2010). Because of his skills, Erhartič was employed at the Anton Melik Geographical Institute of the Research Center of the Slovenian Academy of Sciences and Arts, where he primarily dealt with nature conservation in various projects. He dedicated himself to natural and cultural heritage in towns (Smrekar, Erhartič and Šmid Hribar 2011b), in the countryside (Smrekar et al. 2014), and especially in the mountains (Erhartič 2012; Zorn et al. 2015; Figure 1).

\section{A brief outline of Erhartič's heritage research}

During his relatively brief research career, Erhartič published many works on natural and cultural heritage, and his works dedicated to geomorphological heritage stand out in particular. In these, he was primarily oriented toward their evaluation (Erhartič 2010a, 2010b; Erhartič, Komac and Zorn 2012). He also dedicated himself to the analysis of landforms (Erhartič 2007) and geodoversity (Erhartič and Zorn 2012). He was one of the few people to deal with geomorphological heritage from the perspective of geomorphic processes (Komac, Zorn and Erhartič 2011) that either shape it or »destroy« it. Using the examples of rockfalls that considerably reduced the height of Čedca Falls (once the highest in Slovenia) in 2008 (Triglav Čekada and Zorn 2014) and the effects of the 2007 flash floods that destroyed the Franja Partisan Hospital from the Second World War, which is on the European heritage list, he drew attention to the dynamic character of the landscape (Erhartič and Jelenko 2010), which is not always apparent and which in some manner

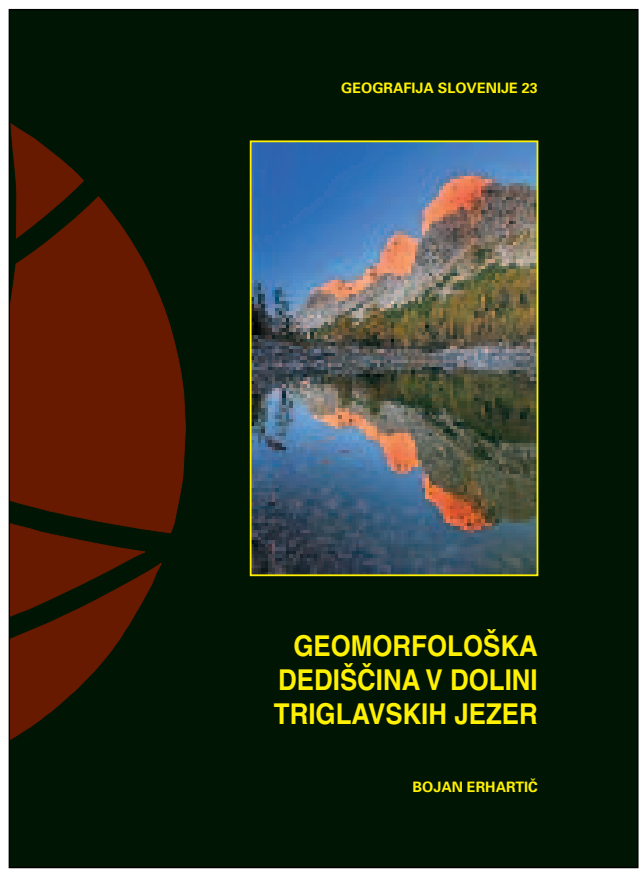

Figure 1: Erhartič's volume on the Triglav Lakes Valley, in which he evaluated its geomorphological heritage (Erhartič 2012). 
also internally conflicts with the idea of nature conservation. In addition, he described the development of people's relationship to heritage in karst studies, with special attention to tourism (Zorn, Erhartič and Komac 2009, 2012). In Slovenia, which is known for its great diversity of natural values (Ciglic \& Perko 2013; Erhartič, Zorn and Komac 2013; Perko, Hrvatin and Ciglič 2015), tourism was also initially »research tourism« because it was based on many visits by foreign researchers. This is especially true for the Kras (Karst) Plateau in southwest Slovenia (Smrekar et al. 2007), which is considered the "cradle« of karst studies (Zorn, Erhartič and Komac 2009; Ferk and Zorn 2015).

Erhartič was one of the rare geography researchers in Slovenia that sought to evaluate natural and cultural heritage as a whole. "In nature everything is connected and equally important, and people perceive both tangible and intangible values in it « (Erhartič 2012,34). It is therefore no surprise that, in addition to unspoiled nature, he was also interested in issues of protecting nature and cultural heritage in the countryside and especially in urban areas (Smrekar, Erhartič and Šmid Hribar 2011a; Smrekar et al. 2014). This is also confirmed by his productive participation in projects on plot gardening in Ljubljana (Breg Valjavec et al. 2008), values of Tivoli, Rožnik, and Šiška Hill Nature Park (Smrekar, Erhartič and Šmid Hribar 2011a), and interpretation of heritage in the Ljubljana Marsh Nature Park (Smrekar et al. 2014). In the case of the Tivoli, Rožnik, and Šiška Hill Nature Park, he determined »that green areas are one of the key factors for pleasant living " (Smrekar, Erhartič and Šmid Hribar 2011a: 120). In another place he wrote that its "main value [lies] ... in offering a diverse experience of nature and the opportunity for psychological relaxation and recreation in a natural environment « (Smrekar, Erhartič and Śmid Hribar 2011b, 109). Because he was aware of how man can upset the natural balance, it is no surprise that he saw the "necessity of ... zoning with optimal distribution of activities « (Smrekar, Erhartič and Šmid Hribar 2011a, 124). In the same publication, he also wrote that in "recent times... there has been a strong public emphasis on nature conservation aspects of the area, but considerably less on its cultural significance, which needs to be balanced in the future (Smrekar, Erhartič and Šmid Hribar 2011a, 109). He concluded the same for the town of Idrija: »The Idrija area is a nice example of man's adaptation to natural endowments. Nature defines culture, and culture protects nature. This harmony is especially visible in the mix of natural, cultural, and technical heritage " (Erhartič and Šmid Hribar 2010, 76). Elsewhere he wrote: "Similarly to nature conservation, in recent years the protection of cul-

Figure 2: Erhartič masterfully combined photography and research in his study of heritage.

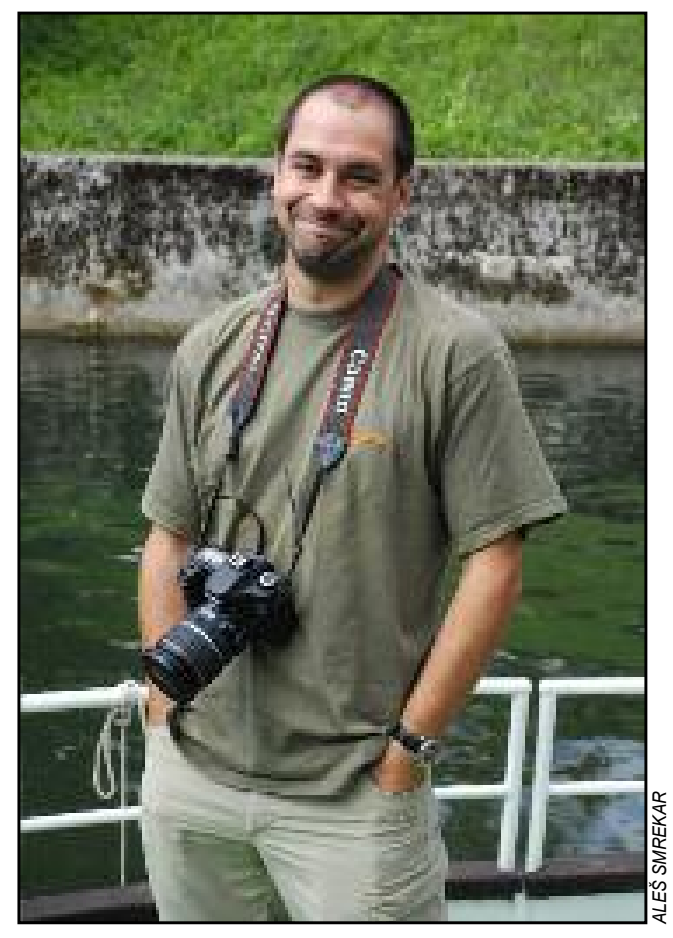


tural heritage has seen the increasing establishment of the doctrines of comprehensive conservation and active management of protected monuments (Erhartič 2014, 40).

\section{Mountains: the unifying theme of Erhartič's research work}

Love for the mountains directed Erhartičs basic research work toward Alpine landscapes (Figure 2). This is where, as a student, he produced his bachelor's thesis, in which he examined the applicability of constructed wetlands at mountain lodges in Triglav National Park (Erhartič 2004). For each mountain lodge he worked out an assessment of the suitability of building a wastewater treatment plant and a proposal for solving the problem using a constructed wetland. Even at that time, he understood the broader context of environmental protection, and he wrote that it is "necessary to emphasize that wastewater treatment plants are not the optimal solution ... Much more important is the adoption of preventive measures « (Erhartič 2008,64 ), such as reducing water use, and thus the quantity of wastewater. He also conducted his doctoral fieldwork in Slovenia's only national park, in its core area: the Triglav Lakes Valley (Erhartič 2012; Figure 1). Posthumously, he contributed to a volume commemorating the ninetieth anniversary of its protection (Zorn etal. 2015). He assessed the geomorphological heritage in the Triglav Lakes Valley, where he stumbled across the problem of subjectivity, which he felt was "an unavoidable evil, but it is necessary to reduce the impact of subjective judgments as much as possible (Erhartič 2012, 172). He took an active role in studying the Triglav Glacier as an indicator of climate change in the southeastern Alps (Erhartič and Polajnar Horvat 2010).

\section{Evaluation of natural heritage}

For Erhartič, the question of a scholarly approach to evaluating natural heritage was such a great challenge that he dedicated his doctoral research to it (Erhartič 2011, 2012). In it, he studied the geomorphological heritage in the Triglav Lakes Valley and carried out a scientific evaluation of landforms as geomorphological

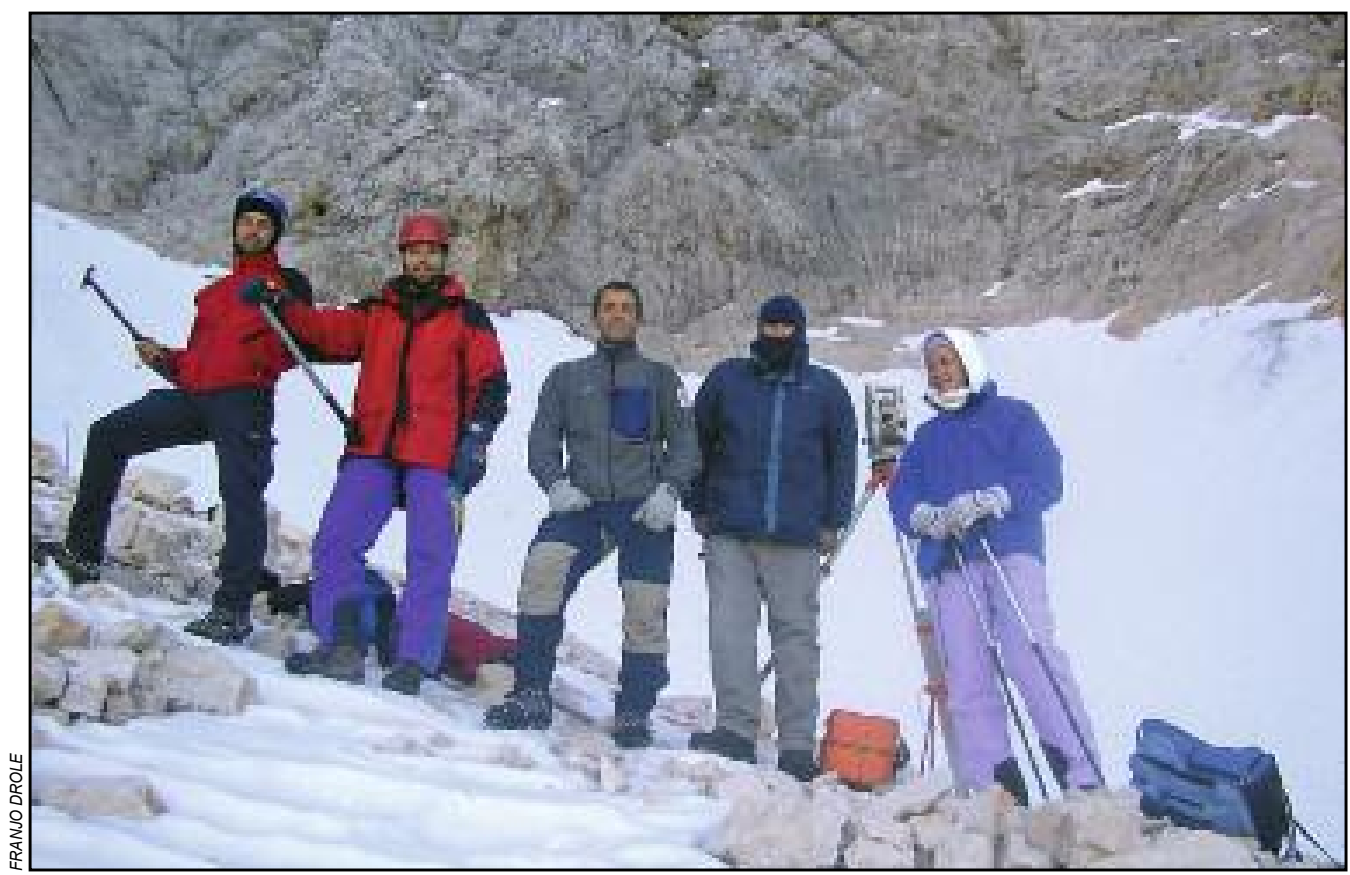

Figure 3: For Erhartič (first from the left), the mountain landscape was a point of departure for research. 


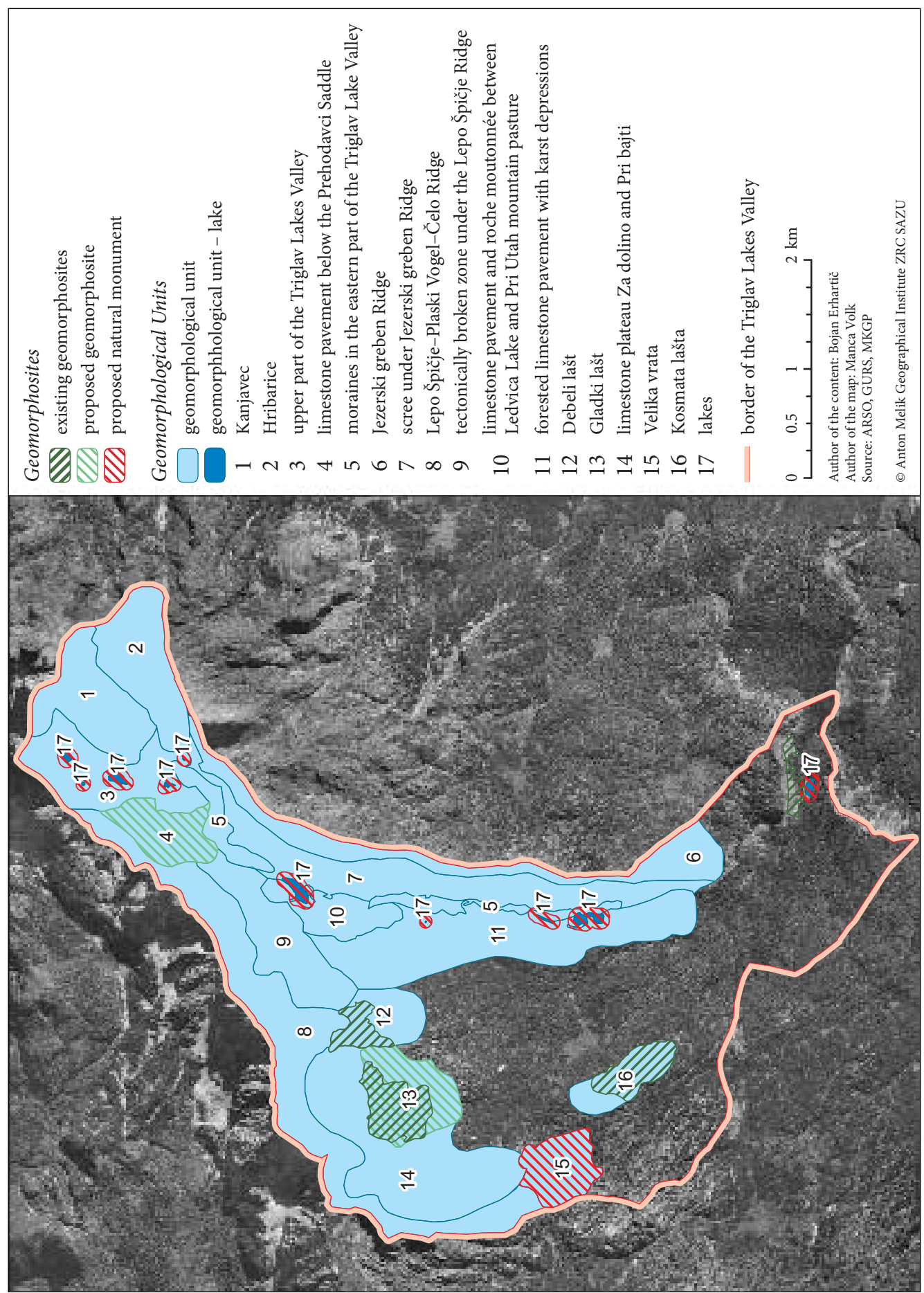

Figure 4: Geomorphological units in the Triglav Lakes Valley and proposals for geomorphological heritage and its protection (Erhartič 2011, 139, 196; Erhartic and Zorn 2012, 60). 
heritage. It seems that his participation in the workshop Mapping Geoheritage, which the International Association of Geomorphologists held in Lausanne in 2008 and which focused on the evaluation of geomorphological heritage, was a milestone for his research (Regolini-Bissig and Reynard 2010). This was where, as a doctoral student, he became acquainted with the basics of mapping geomorphological heritage, and especially with the methods of evaluating it.

He evaluated landforms using the Swiss method (Reynard et al. 2007), which for the scientific value takes into account the following criteria: rareness, representativeness, integrity, and paleogeographic value. The method also uses additional values, such as ecological, aesthetic, cultural, and economic values (Erhartič 2011, 2012). The result of such analysis is an assessment of the value of a particular landscape or its parts from the perspective of geomorphological heritage. In the Triglav Lakes Valley, he classified the landforms into seventeen geomorphological units based on their genesis and the processes that (re)shape them (Figure 4). Erhartič was also engaged at the applied level, and in his conclusion he suggested which areas should be given additional protection due to their high research or aesthetic value or due to the rarity of features found there.

His work was also important because it added to the methods used up until then for evaluating landscapes from the perspective of geomorphological heritage (Reynard and Coratza 2016). Such evaluation was started by Panizza in Italy (Panizza and Piacente 1993; Panizza 2001, 2003), and his work was continued in neighboring countries. Thus, in addition to the Italian method, there gradually also appeared Swiss, Spanish (Serrano and Gonzales-Trueba 2005), Portuguese (Pereira, Pereira and Caetano Alves 2007), and other methods (e.g., Coratza and Giusti 2005) for assessing geomorphological heritage. Erhartič's contribution can easily be ranked alongside these and one may also speak about a »Slovenian method « (Table 1; Erhartič 2010).

Erhartič dedicated special attention to natural heritage in the former mining town of Idrija, which is on the UNESCO list of world heritage sites because of its five-hundred-year heritage of mercury mining (Zorn, Nared and Razpotnik Visković 2015). Erhartič's comprehensive treatment of territory in the Municipality of Idrija from the perspective of natural heritage is probably the apex of the application of his expertise (Erhartič and Šmid Hribar 2010; Nared, Erhartič and Razpotnik Visković 2013). His work has broader social significance because he showed that it is possible to use research findings to solve current challenges (Goluža and Erhartič 2014).

Table 1: Geomorphological heritage assessment criteria according to the Slovenian method (Erhartič 2010, 304).

\begin{tabular}{|c|c|}
\hline & Short description \\
\hline Exceptionality & $\begin{array}{l}\text { We assess exceptionality within the typological group according to the frequency of appearance, dimensions and other } \\
\text { characteristics. Usually the comparison is made within Slovenia, sometimes even wider. We distinguish the absolute and } \\
\text { the relative rarity of a feature, exceptional dimensions and extraordinary or unique landforms. }\end{array}$ \\
\hline Representativeness & $\begin{array}{l}\text { The criterion for representativeness is used for all objects or areas of natural heritage on the basis of which literature offers } \\
\text { descriptions of specific natural features, landforms, processes, or for those objects and areas which are characteristic of or } \\
\text { are evidently formed representatives of a specific type of natural features. }\end{array}$ \\
\hline Complexity & $\begin{array}{l}\text { Objects or areas of geomorphological heritage frequently intertwine and together form a new value. This can happen } \\
\text { due to a peculiar combination of values within an area or due to the merging of objects into bigger, connected units. } \\
\text { The value of such complex areas is bigger than the sum of all individual values, and one individual object as part of } \\
\text { a bigger unit is assessed on a higher level. }\end{array}$ \\
\hline Ecological aspect & $\begin{array}{l}\text { Assessment on the basis of the ecological aspect takes into account ecosystems with higher levels of protection, ecosystems } \\
\text { with greater diversity of habitats or species (stable ecosystems), as well as ecosystems that are rare. }\end{array}$ \\
\hline Cultural aspect & $\begin{array}{l}\text { The cultural aspect is the most subjective one, as it defines our relationship towards our heritage. It is based on the } \\
\text { following criteria: expressiveness, symbolic value, diversity and the landscape aspect (the aesthetic relationship of } \\
\text { natural heritage towards the surrounding environment). }\end{array}$ \\
\hline Exploitation aspect & $\begin{array}{l}\text { The exploitation aspect (scientific and educational aspects) was used regarding the protection of the heritage and not for } \\
\text { its assessment. The assumption was made that all objects which match at least one of the aforementioned criteria are } \\
\text { important for scientific study. The suggestion of intended use - what is acceptable from perspective of natural heritage } \\
\text { conservation - derives from the evaluation of the conservation aspect and the accompanied exploitation or function. } \\
\text { This intended use can partly or fully match other exploitations of space, or it can exclude them. }\end{array}$ \\
\hline
\end{tabular}




\section{Aesthetics and interpreting nature}

Erhartič was among the first to deal with the aesthetic evaluation of geomorphological heritage in Slovenian geography (Smrekar and Erhartič 2015; see also Smrekar, Polajnar Horvat and Erhartič 2016 in this special issue), or the issue of beauty as a criterion for classifying landforms among natural values. He took issue with aesthetic evaluation, because, as an old Slovenian proverb says, Vsake oči imajo svojega malarja (essentially, 'to each his own'; Erhartič 2012). Later he carried out an extensive survey on the beauty of landscape forms and determined that "people are most attracted to landforms with a water element; one can speak about collective patterns of perceiving nature's beauty « (Smrekar and Erhartič 2015, 123).

Erhartič's interest in the »beauty of nature « proceeded from his many years of planned work in (geographical) photography. His colleagues recall how precisely he planned his trips, which were often oriented toward learning about and documenting natural and especially geomorphological heritage. Thus it is not surprising that, due to his outstanding familiarity with various landscapes around the world and their natural and cultural characteristics, he was distinguished by exceptional knowledge and breadth, patience, and photographic talent. This is reflected in his photos, which grace many of the publications by the Anton Melik Geographical Institute of the Research Center of the Slovenian Academy of Sciences and Arts and beyond, and also in his travel lectures, in which he emphasized a comprehensive experience of the landscape, including with music. The Anton Melik Geographical Institute of the Research Center of the Slovenian Academy of Sciences and Arts holds nearly 218,000 of his "geographical " photos (Figure 2), which he took on his many trips to more than forty countries on five continents.

In the conclusions to his doctoral dissertation, he indicated what his next challenges would be: »visitor education and interpretation of geomorphological heritage " (Erhartič 2008). Soon afterwards, he was offered the opportunity to create an interpretation of the landscape along the Iška River in the Ljubljana Marsh Nature Park (Figure 5; Smrekar et al. 2013, 2014; see also Smrekar et al. 2016 in this special issue). He was aware that one of the key tasks is "to enrich experience and ensure visitors' satisfaction «, whereby he did not forget that it is necessary to inform people »without significant negative impacts on the environment (Smrekar et al. 2014, 121, 123).

\section{THE IŠKA RIVER MEANDER NATURE TRAIL}

\section{A FAN BUILT UP}

Have you noticed that the landscape around you is different than in the Iška Gorge or in the Ljubljana Marsh near the village of Lipe? You're standing on a fan-a fan-shaped accumulation of alluvial deposits. It was piled up by the river, which loses power as it enters the plain from the gorge, and so it starts to deposit material. It gradually deposits so much gravel that it fills up its own riverbed, and so then it
floods and seeks a new bed. While looking for the ideal bed, floods and seeks a new bed. While looking for the ideal bed, the lška River has constantly changed its course-like a
dragon wagging its tail left and right. In the past few centuries people have tried to tame this dragon, and that's probably why they pushed it under the foothills of Mount Krim. Its naturally twisting course, full of meanders, has been replaced by a rather straight river channel.

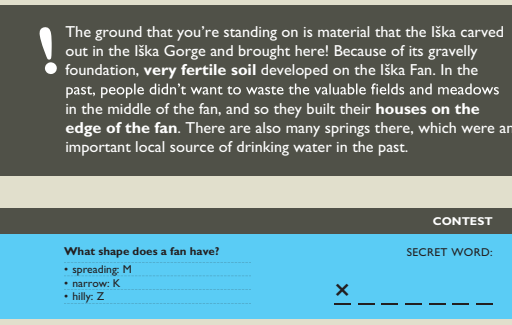

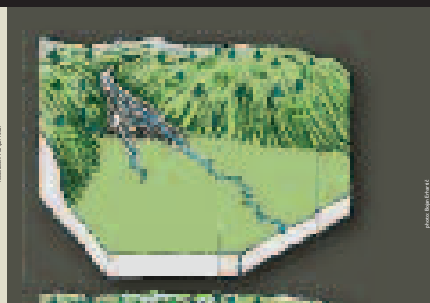

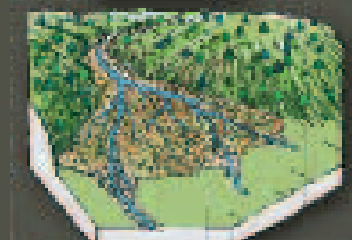

The size of the fan can only be appreciated from a bird's-eye view.

4 As elevation differences increased, the lška carried more and more material, depositing Here's a three-step simplification of how it formed.

Shallow soil that's good for farming developed on the gravelly alluvium. Scientists call this eutric brown soil.
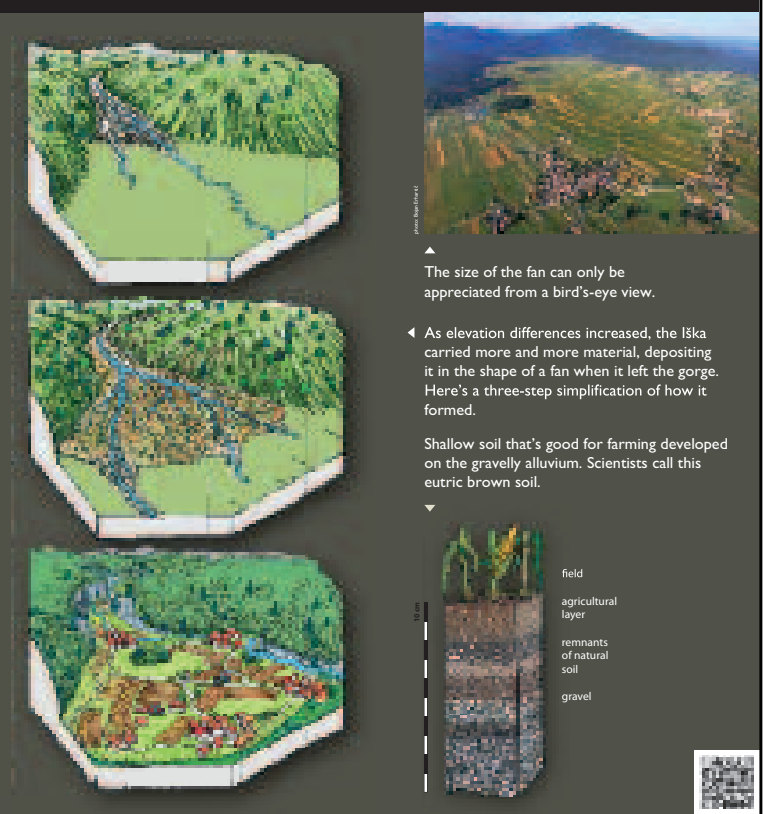

Figure 5: Interpretation of natural heritage on the nature trail along the lška River: the example of a fan (Smrekar et al. 2013). 


\section{Conclusion}

This volume of the journal Acta geographica Slovenica is dedicated to the geographer Bojan Erhartič (Figure 6). In just a few years at the beginning of the twenty-first century, Erhartič had a strong impact on Slovenian geography. His greatest contribution was to place it on the map of countries where geographers deal with geomorphological heritage. He drew attention to the fact that it is necessary to understand natural values at multiple levels, especially at the intrinsic level, which encompasses understanding their genesis and transformation through geomorphic processes. Through his work in photography, he emphasized the importance of cultural and aesthetic elements. He made a lasting contribution to the socioeconomic, educational, and functional aspects of geomorphological heritage. His contribution to environmental protection also cannot be overlooked. He specifically drew attention to the long-term significance of nature conservation: "In the preservation of natural heritage it is essential to recognize that we are not protecting against nature, but against man, for man. We are preserving nature, which is in a state of dynamic equilibrium and gradual change. Man should not interfere in these processes and, if life and property are threatened, he should only guide them! (Erhartič and Jelenko 2010, 26). This thought was reflected not only in his research, but also in his private life.

Bojan Erhartič summed up his relationship to geography, protection of nature and the environment, and man's place in the landscape with the following thought (Smrekar et al. 2014, 119):

"An important mission of protecting the environment is also making it possible to experience the heritage that has been preserved. Protected areas are suitable for learning, education, recreation, and "soft" tourism. Visits to such areas should be planned, guided, and supervised, because the sensitivity of landscapes means that visits may disturb them, which is contrary to the primary goals of protecting and safeguarding unique and diverse landscapes."

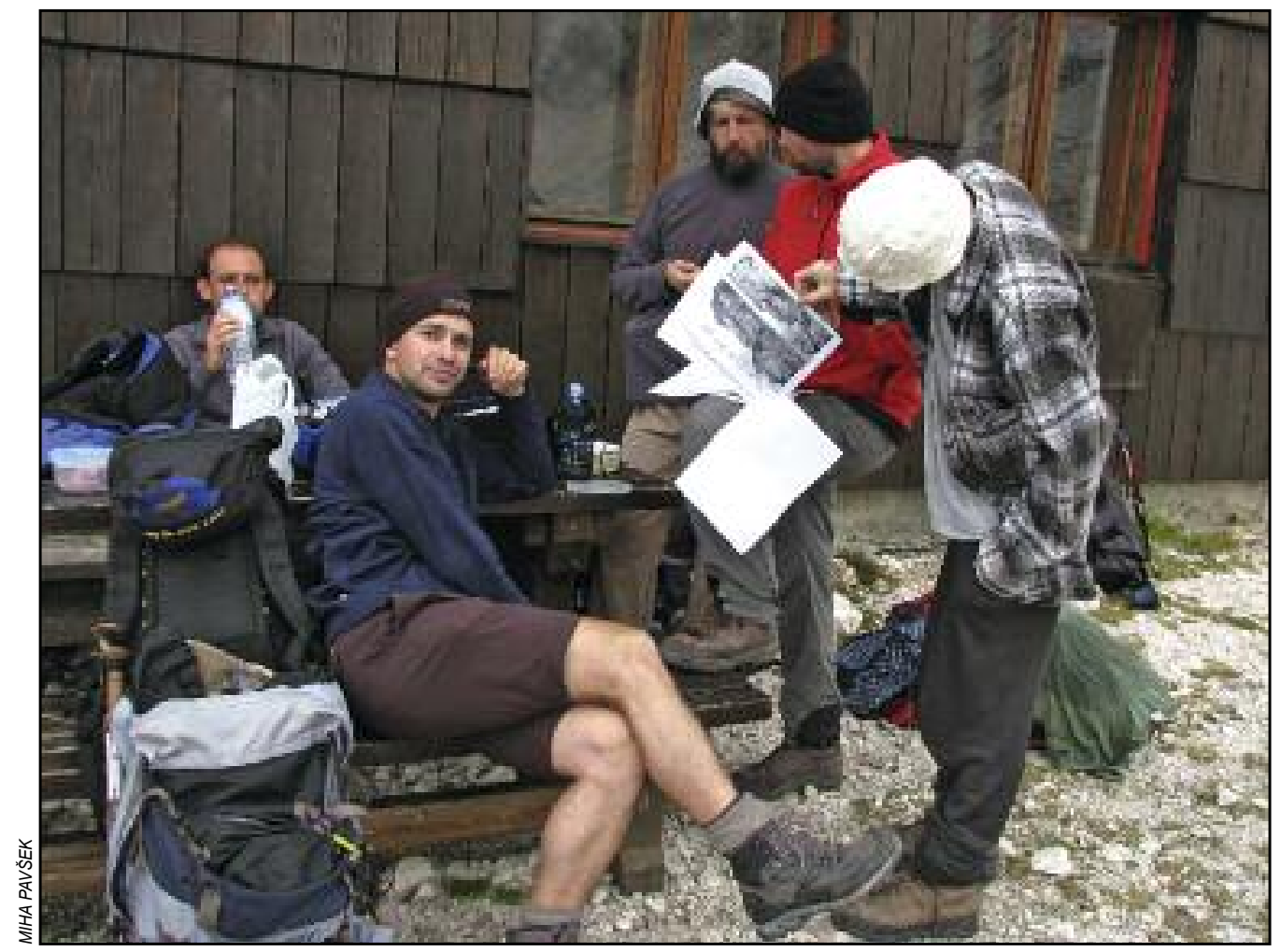

Figure 6: Erhartic (foreground) had a sense of humor that endeared him to his colleagues. 


\section{References}

Breg Valjavec, M., Erhartič, B., Kladnik, D., Smrekar, A. 2009: Vrtički. Vrtičkarstvo v Ljubljani. Geografija Slovenije 21. Ljubljana.

Ciglič, R., Perko, D. 2013: Europe's landscape hotspots. Acta geographica Slovenica 53-1. DOI: http://dx.doi.org/ $10.3986 /$ AGS53106

Coratza, P., Giusti, C. 2005: Methodological proposal for the assessment of the scientific quality of geomorphosites. Il Quaternario 18-1.

Erhartič, B. 2004: Presoja uporabnosti rastlinskih čistilnih naprav pri planinskih postojankah Triglavskega narodnega parka. B.Sc. Thesis, Filozofska fakulteta Univerze v Ljubljani. Ljubljana.

Erhartič, B. 2007: Reliefne oblike kot geodiverziteta (geomorfološka naravna dediščina). Dela 28. DOI: http://dx.doi.org/10.4312/dela.28.5.59-74

Erhartič, B. 2008: Presoja uporabnosti rastlinskih čistilnih naprav pri planinskih postojankah Triglavskega narodnega parka. Geografski vestnik 80-2.

Erhartič, B. 2010a: Geomorphosite assessment. Acta geographica Slovenica 50-2. DOI: http://dx.doi.org/ 10.3986/AGS50206

Erhartič, B. 2010b: Conserving geoheritage in Slovenia through geomorphosite mapping. Géovisions 35.

Erhartič, B. 2011: Naravovarstveno vrednotenje geomorfološke dediščine v Dolini Triglavskih jezer z metodo geomorfološkega kartiranja. Ph.D. Thesis, Biotehniška fakulteta Univerza v Ljubljani. Ljubljana.

Erhartič, B. 2012: Geomorfološka dediščina v Dolini Triglavskih jezer. Geografija Slovenije 23. Ljubljana.

Erhartič, B. 2014: Ohranjanje kulturne dediščine. Upravljanje območij s kulturno dediščino, Capacities 2. Ljubljana.

Erhartič, B., Jelenko, I. 2010: Vpliv naravnih nesreč na naravno in kulturno dediščino. Od razumevanja do upravljanja, Naravne nesreče 1. Ljubljana.

Erhartič, B., Komac, B., Zorn, M. 2012: Geomorphosites in Slovenia. Geomorphosites 2009: raising the profile of geomorphological heritage through iconography, inventory and promotion. Paris.

Erhartič, B., Polajnar Horvat, K. 2010: Slovenia's Triglav glacier as an indicator of climate change. Bulgarian Journal of Meteorology and Hydrology 15-1.

Erhartič, B., Šmid Hribar, M. 2010: Naravna dediščina v občini Idrija. Na prelomnici: razvojna vprašanja občine Idrija, Capacities 1. Ljubljana.

Erhartič, B., Zorn, M. 2012: Geodiversity and geomorphosite research in Slovenia. Geografski vestnik 84-1.

Erhartič, B., Zorn, M., Komac, B. 2013: Geoturizem kot nova razvojna perspektiva Slovenije. Nove razvojne perspektive, Regionalni razvoj 4. Ljubljana.

Ferk, M., Zorn, M. 2015: Kras - večpomenski izraz z mednarodno veljavo. Kronika 63-3.

Goluža, M., Erhartič, B. 2014: Smernice Unesca za ohranjanje kulturne dediščine. Upravljanje območij s kulturno dediščino, Capacities 2. Ljubljana.

Komac, B., Zorn, M., Erhartič, B. 2011: Loss of natural heritage from the geomorphological perspective: Do geomorphic processes shape or destroy the natural heritage? Acta geographica Slovenica 51-2. DOI: http://dx.doi.org/10.3986/AGS51306

Nared, J., Erhartič, B., Razpotnik Visković, N. 2013: Including development topics in a cultural heritage management plan: mercury heritage in Idrija. Acta geographica Slovenica 53-2. DOI: http://dx.doi.org/ 10.3986/AGS53404

Panizza, M. 2001: Geomorphosites: concepts, methods and example of geomorphological survey. Chinese Science Bulletin 46-1. DOI: http://dx.doi.org/10.1007/BF03187227

Panizza, M. 2003: Karst landforms as geomorphosites. Dela 20. DOI: http://dx.doi.org/10.4312/dela.20.2.19-26

Panizza, M., Piacente, S. 1993: Geomorphological assets evaluation. Zeitschrift für Geomorphologie 87.

Pereira, P., Pereira, D., Caetano Alves, M. I. 2007: Geomorphosite assessment in Montesinho Natural Park (Portugal). Geographica Helvetica 62-3.

Perko, D., Hrvatin, M., Ciglič, R. 2015: A methodology for natural landscape typification of Slovenia. Acta geographica Slovenica 55-2. DOI: http://dx.doi.org/10.3986/AGS.1938

Regolini-Bissig, G., Reynard, E. (eds.) 2010: Mapping Geoheritage. Géovisions 35. Internet: http:/igd.unil.ch/www/ geovisions/35/Geovisions35.pdf (11. 12. 2015).

Reynard, E., Coratza, P. 2016: The importance of mountain geomorphosites for environmental education. Acta geographica Slovenica 56-2. DOI: http://dx.doi.org/10.3986/AGS.1684 
Reynard, E., Fontana, G., Kozlik, L., Scapozza, C. 2007: A method for assessing »scientific« and »additional values« of geomorphosites. Geographica Helvetica 62-3.

Serrano, E., González-Trueba, J. J. 2005: Assessment of geomorphosites in natural protected areas: the Picos de Europa National Park (Spain). Géomorphologie: relief, processus, environnement 3. DOI: http://dx.doi.org/ 10.4000/geomorphologie.364

Smrekar, A., Erhartič, B. 2015: Estetika naravne pokrajine. Dolina Triglavskih jezer. Geografija Slovenije 32. Ljubljana.

Smrekar, A., Erhartič, B., Šmid Hribar, M. 2011a: Krajinski park Tivoli, Rožnik in Šišenski hrib. Georitem 16. Ljubljana.

Smrekar, A., Erhartič, B., Šmid Hribar, M. 2011b: Pomen zavarovanih območij v mestnih središčih na primeru krajinskega parka Tivoli, Rožnik in Šišenski hrib. Razvoj zavarovanih območij v Sloveniji, Regionalni razvoj 3. Ljubljana.

Smrekar, A., Erhartič, B., Šmid Hribar, M., Tiran, J. 2013: Pot ob reki Iški - »Okljuk« = The Iška river meander nature trail. Internet: http://giam2.zrc-sazu.si/sites/default/files/ig_table_ang_splet.pdf(11. 12. 2015).

Smrekar, A., Polajnar Horvat, K., Erhartič, B. 2016: The beauty of landforms. Acta geographica Slovenica 56-2. DOI: http://dx.doi.org/10.3986/AGS.3039

Smrekar, A., Šmid Hribar, M., Tiran, J., Erhartič, B. 2014: Interpretacija okolja na primeru Ljubljanskega barja. Georitem 24. Ljubljana.

Smrekar, A., Šmid Hribar, M., Tiran, J., Erhartič, B. 2016: A methodological basis for landscape interpretation: The case of the Ljubljana Marsh. Acta geographica Slovenica 56-2. DOI: http://dx.doi.org/ 10.3986/AGS.875

Smrekar, A., Urbanc, M., Kladnik, D., Breg Valjavec, M., Erhartič, B., Nared, J., Petek, F. 2007: Kras kot razvojni potencial: $\mathrm{v}$ iskanju ravnovesja med varovanjem in razvojem. Veliki razvojni projekti in skladni regionalni razvoj, Regionalni razvoj 1. Ljubljana.

Triglav Čekada, M., Zorn, M. 2014: Ugotavljanje intenzivnosti geomorfnih procesov s pomočjo posnetkov cikličnega aerofotografiranja Slovenije. Geografski vestnik 86-2. DOI: http://dx.doi.org/10.3986/GV86206

Zorn, M., Erhartič, B., Komac, B. 2009: La Slovénie, berceau du géotourism karstique. Karstologia 54.

Zorn, M., Erhartič, B., Komac, B. 2012: The beginnings of karst geotourism: karst geotourism in Slovenia. Geomorphosites 2009: raising the profile of geomorphological heritage through iconography, inventory and promotion. Paris.

Zorn, M., Nared, J., Razpotnik Visković, N. 2015: Creating new opportunities for an old mining region: The case of Idrija (Slovenia). Ekonomska i ekohistorija 11.

Zorn, M., Smrekar, A., Skoberne, P., Šmuc, A., Brancelj, A., Dakskobler, I., Poljanec, A., Peršolja, B., Erhartič, B., Ferk, M., Hrvatin, M., Komac, B., Ribeiro, D. 2015: Dolina Triglavskih jezer. Geografija Slovenije 32. Ljubljana. 
